\title{
On German Unity ${ }^{1}$
}

\author{
LT GEN DR H. OLBOETER \\ Director Personnel of the German Federal Ministry of Defence
}

On 3 October 1990 the division of Germany into two states came to an end. The German Democratic Republic (GDR) acceded to the Federal Republic of Germany and in doing so ceased to exist. This epoch-making event took place peacefully and in agreement with all Germany's friends, allies and European neighbours. United at the heart of Europe, Germany gained full sovereignty over its internal and external affairs. Thus, after 40 years of division, a victory was won by the feeling of solidarity and the wish of the people in both parts of Germany to live together in one country that guarantees freedom, democracy and the rule of law.

To help you appreciate the situation more fully, I would like to take a brief look at our history.

The division of Germany was a direct consequence of the Second World War. In view of its defeat, Germany, as it stood before the outbreak of war, was divided within its borders into four zones for the purpose of occupation. Each of these zones was allocated to one of the victorious powers, these being the USA, Great Britain, France and the Soviet Union, and a special area - the capital city of Berlin - was occupied jointly by the four powers.

Owing to the ideological differences between the western Allies and the Soviet Union, however, their alliance was destined to collapse. The western democracies, in particular the USA, boosted the destroyed economies of Europe by injecting billions of dollars. This became known as the Marshall Plan. The Soviet Union under Stalin, on the other hand, cut off Eastern Europe from the sphere of influence of the West. The growing resistance of Eastern European countries against the communist hegemony put increasing pressure on the Soviet Union that led to the division of Berlin into an eastern and a western sector and finally to a total blockade of Berlin in 1948. However, this attempt to exclude the western Allies failed. Berlin was supplied with goods thanks to an impressively organized

Paper presented on 2 May 1997, to the staff and students of the Faculty of Military Science, University of

Stellenbosch (Military Academy). 
airlift. When the blockade was lifted in the spring of 1949, the climate between the western Allies and the population in the western occupied zones had changed. Enemies had now become friends and partners with common interests and values. Berlin, formerly the capital city of the Third Reich, now became a symbol of freedom.

In 1949 two states came into being whose basis, dependencies and legitimization could not have been more different. The democratically-elected Laender parliaments in the west and the "Socialist Unity Party of Germany" (SED) in the Soviet zone of occupation laid the foundations for the constitutions of both states.

The preamble of the Basic Law of the Federal Republic of Germany stipulates that "the entire German people is called on to achieve by free self-determination the unity and freedom of Germany." This strong awareness of national unity and the powerful feeling of solidarity on the part of Germans remained unchanged for over 40 years and was a yardstick for the political policies of all federal governments that followed. Whereas in the post-war years the Federal Republic of Germany overcame the problems of reconstruction quicker than expected in a vehement phase of growth (a phenomenon known today as the "economic miracle"), the GDR witnessed the planned establishment of socialism under Soviet hegemony with the collectivization of industry and agriculture. Supply problems and the exaggerated goals of the planned economy led to a popular uprising in the GDR on 17 June 1953 that was suppressed, however, with the help of Soviet tanks.

The GDR entered the Warsaw Pact, while the Federal Republic became a partner in the Western European Union, a member of NATO and a founding member of the European Economic Community (EEC). The German question, in other words the recognition of two German states and the recognition of the GDR by other countries, was yet to be given a political answer.

The socialistic course of the GDR and the incessantly low standard of living suffered by the people there drove the country into a serious economic crisis and led to a mass exodus to the West. With the construction of the wall around West Berlin on 13 August 1961 and the cordoning off of the entire border to the Federal Republic, the leadership of the GDR put a stop to the flow of refugees from east to west. Justified as an "antifascist defensive wall", the Berlin wall tore friends, families and neighbours apart but did in fact contribute to the stabilization of the GDR. In the years that followed, the industry of the GDR became the strongest in the Soviet bloc.

The Federal Republic of Germany experienced a sustained economic upswing and became one of the leading industrial and trading countries of the world. The "Ostpolitik", which at first stagnated after the construction of the Berlin wall, was followed by a policy of small steps. Correspondence between the heads of government began and promised relief for the inhabitants. The SED reacted to the brisk personal traffic between the two states with a campaign of ideological delimitation. The state-controlled media portrayed the Federal Republic as being a horror scenario of housing shortages, crime and inflation. It was even prohibited to receive western television programmes. The low standard of 
living and the shortage of foreign exchange forced the government of the GDR to borrow large sums of money in the West, even from the Federal Republic.

The turning point came in December 1987 when the USA and the Soviet Union signed a treaty on the abolition of medium-range nuclear missiles. Under "glasnost" and "perestroika", the Soviet president Mikhail Gorbachev promised to change conditions in the Soviet Union and launched an international offensive to reduce international tension. The leadership of the GDR, who saw themselves "bound forever and irrevocably with the Soviet Union" failed to adapt to the new realities.

1989 witnessed a rapid increase in the size and speed of events. After the true extent of the economic crises became known and socialist society ran aground, a mass exodus began of GDR citizens via Hungary and Austria to the Federal Republic in August 1989. Dissatisfaction and anger at living conditions in the GDR drove hundreds of thousands of people week for week to the streets where impressive and peaceful demonstrations were held under the mottoes "We are one people" and "Germany - a united fatherland". Under popular pressure and without the backing of the neighbouring Soviet states, the government of the GDR and the SED Politburo stepped down in November 1989. On 9 November 1989 the borders to the Federal Republic were opened. The Wall had fallen.

From this point on, the Federal Government remained in uninterrupted negotiations with the newly elected GDR parliament and entered into a number of agreements which irrevocably led to the reunification of the two German states. On 1 July 1990, the Monetary, Economic and Social Union came into being. The final breakthrough was achieved by the German Federal Chancellor, Helmut Kohl, at a meeting with Soviet President Mikhail Gorbachev in June 1990 in the Caucasus. The most important results of the negotiations were:

- that the united Germany would receive full sovereignty and be free to choose to which alliance it wished to belong;

- that only after a period of 3 to 4 years, and until such time as the Soviet Union had withdrawn its approximately 340,000 soldiers, could NATO structures be extended to the territory of the GDR; and

- that the armed forces of the united Germany would be reduced to a personnel strength of 370,000 soldiers within a period of 3 to 4 years.

In return, the Soviet Union was promised a massive loan to help overcome its serious economic and social problems as well as generous financial support for the withdrawal of its troops from the erstwhile GDR and for the construction of housing in the Soviet Union to house the homecoming soldiers. In a separate treaty concluded with Poland, the existing border along the Oder and Neisse rivers was confirmed as binding.

Nothing else stood in the way of achieving German Unity. With the "Agreement on the Establishment of German Unity", the social, economic and political foundations were laid for German unity with the objective of creating uniform living conditions. 3 October 1990 became the Day of German Unity. 
Germany's western European neighbours also responded to unification with uncertainty and concern at first. However, fears proved to be unfounded that Germany could assume a predominant position on the European continent in view of its growth in population from 60 to 80 million inhabitants and its economic strength. The united Germany has proven itself to be a reliable partner in Europe on account of its full integration in the Atlantic alliance and its firm ties to all areas of the European community. In UN-led peacemaking and peacekeeping measures, the Federal Republic has participated, for example, in missions in Cambodia, Somalia and at present in former Yugoslavia. As a central objective of German policy aimed at a new European architecture, the Federal Republic supports the enlargement of the European Union and NATO to include countries interested in joining these organizations - such as Poland, Hungary, the Czech Republic, Slovakia or Slovenia - in order to contribute to the stabilization of Eastern Europe.

Seen particularly from an economic perspective, German unity demands that we exert a great deal of energy. The economy of the GDR had run out of steam. In order to adapt it to the new political and economic realities, a "Trust Agency" (Treuhandgesellschaft) was established whose task it was to privatize state property and some 13,000 industrial or agricultural enterprises. In order to secure incomes and pensions, support companies and improve the infrastructure in the new Laender, transfer payments from the old Laender of around DM 180 billion are made every year. By the end of 1996, these payments totalled DM 1,000 billion which constitutes a substantial part of the enormous government debt. Of course, the financial sacrifices which must be made to unite Germany's two halves by sharing the burden, hinder east and west from growing together more rapidly in peoples' hearts and thereby make inner unity all the more difficult to achieve.

Among the unique challenges of unification was the adoption of personnel and materiel of the former National People's Army (NPA) by the Bundeswehr. Unlike the last government of the GDR, which was at first of the opinion that the NPA could be maintained as an independent entity in the united Germany and continue to exist as a second army alongside the Bundeswehr, the Federal Government rejected from the very beginning both the integration and unification of the two German armed forces, having as they did completely different value systems. The NPA was closely bound to the politics and ideology of the Soviet military and saw the Bundeswehr as a political and social "class enemy" whom soldiers had been taught for decades to hate. Integrated into the centrally controlled Warsaw Pact, its authorized strength of 175,000 soldiers made it extremely well prepared to respond and launch attacks. The operational infrastructure was perfect, weapons and equipment were stored in heated buildings, but little consideration was given to dignified housing and the welfare of the soldiers.

In addition to the NPA, there were further armed organs. These included the border troops, the military forces of the Ministry of State Security, in whose tightly-woven net all soldiers within the armed forces were monitored, and the battle groups of the working class who were responsible for civil emergency preparedness. 
During the unification process, the leadership of the GDR failed to acquire the necessary support for its proposals. It was agreed that there could be only one army for all of Germany under the control of the Federal Minister of Defence.

On 1 October 1990, the dissolution of the Warsaw Pact began with the withdrawal of the GDR. On the same day, the leadership of the NPA dismissed all Generals and Admirals as well as all regular soldiers over the age of 55; the border troops were disbanded. The disbandment of the NPA followed on 2 October. Some 90,000 soldiers (of whom 50,000 were regular and temporary-career volunteers) and 48,000 civilian employees still on the payroll on 3 October 1990, the Day of German Unity, were taken over by the Bundeswehr. They were employed at about 1,500 units and agencies which for the time being were subordinate to a "Bundeswehr Eastern Command" until the Army, Air Force and Navy could take over the tasks at hand. With the new Laender, the Bundeswehr grew from 495,000 soldiers and 183,000 civilian personnel to almost 600,000 soldiers and more than 230,000 civilian personnel. At the same time it was necessary pursuant to the agreements concluded to reduce the size of the pan-German armed forces to 370,000 by the end of 1994 (this figure has since been reduced to 340,000); the number of civilian personnel is to be shrunk to less than 140,000 by the year 2000 . The fair selection of suitable personnel and at the same time the necessary, socially acceptable reduction of personnel demanded a great deal of empathy and care above and beyond the normal call of duty.

Some 21,500 civilian employees were given permanent jobs as workers, salaried employees or civil servants in the defence administration.

The periods of service completed by conscripts in the NPA were set off against the then 15-month (now 10-month) basic military service in the Bundeswehr. Depending on the numbers needed, suitable regular and temporary-career volunteers were able to be taken on, at first for a trial period of two years and thereafter in a permanent appointment. Political officers, employees of the National Security Service and members of the system of military justice were not taken over by the Bundeswehr.

About half of the regular and temporary-career volunteers applied for this interim employment of two years; 6,000 officers, 11,200 NCOs and 800 other enlisted personnel were taken over as temporary-career volunteers for a period of two years. Based on a comparison with soldiers of the Bundeswehr, they were awarded a rank which was often one of two ranks lower than in the NPA; 500 former officers were taken over with an NCO rank. This was, however, in no way a "degradation" in the proper sense of the word. The most important reason lay in the personnel structure of the former NPA. As was the case with all armed forces in the Warsaw Pact, the NPA was extremely "top-heavy". The percentage of officers in the NPA amounted to between 20 and at the end $33 \%$; in the Bundeswehr, by contrast, this figure was only $9 \%$. Jobs such as crew chief for combat aircraft which would be performed in the Bundeswehr by an NCO with the rank of staff sergeant were the responsibility of a captain in the NPA. Higher ranks could be achieved at markedly younger ages. Against this background, adapting ranks to the structures in the 
Bundeswehr was both in accordance with the equal treatment of soldiers in the Bundeswehr and in the interests of the former NPA soldiers to avoid overtaxing them in their new assignments. For this reason, these measures cannot - as I have said - be considered a "degradation".

A total of 15,000 soldiers applied for permanent employment in the Bundeswehr; some 3,000 officers, 7,600 NCOs and 200 other enlisted personnel were in fact taken over.

Soldiers who resigned or were not selected for the Bundeswehr were offered extensive integration assistance in the form of schooling and training programmes for the transition to a civilian career. In addition to financial transition assistance, the Bundeswehr also offered opportunities to attain higher school leaving certificates or complete concrete job training in order to boost chances on the job market which is also saturated in Germany. What is more, for this circle of persons in the Bundeswehr a special "job exchange" was established which featured jobs from all areas of industry, trade or public administration in order to assist civilian placement agencies.

In addition to personnel, the Bundeswehr took over extensive materiel from the holdings of the former GDR including over 10,500 main battle tanks, artillery weapons, aircraft and ships, 80,000 wheeled vehicles, 1.3 million small arms and almost 300,000 tonnes of ammunition of which only a fraction could be used in the now smaller Bundeswehr. The majority was recycled or scrapped at a high cost. Furthermore the material legacy of the NPA included 2,285 military facilities such as barracks, storage sites, training areas, dockyards and airfields which were without exception in a poor state of repair and of which the Bundeswehr can only continue to use a meagre 600 after having incurred modernization costs of more than DM 16 billion. In addition to taking inventory and making decisions on utilization, the Bundeswehr had to observe certain legalities, particularly during the take-over phase. This is why, for example, the enormous ammunition depots could no longer be protected by a high-voltage fence and had to be guarded at enormous personnel costs. The Bundeswehr also had to fall back on experienced personnel of the former NPA in order to secure the safety of the airspace.

In the meantime, the establishment of the Bundeswehr in the new federal Laender is for the most part complete. The "Army of German Unity" is now a reality. The process of integration is under full steam with the transfer of units and installations from the old into the new Laender and the deliberate intermixture of units with soldiers from the east and west. Many members of the former NPA were offered a fair chance and new prospects which they took advantage of in every respect with enthusiasm and loyalty.

The Bundeswehr has experienced a great deal of success in the unprecedented process of taking over the personnel and materiel of an army so utterly different from itself. The individual integration of soldiers and civilian personnel of the former NPA into the unchanged structures of the Bundeswehr is a yardstick for the whole of society in overcoming erstwhile divisions and completing the inner-unification of Germany.

In many appraisals, not least in that of our Federal President, the achievements of the 
Bundeswehr in the process of German unification have been extolled as exemplary, and those of us who were able to play a part are proud of this recognition.

\section{Sources}

Teltschik, Horst. "329 Tage”, Innenansichten der Einigung, Siedler Verlag. Berlin, 1991.

Görtemaker, Manfred. Unifying Germany 1989 - 1990, St. Martin's Press, New York, 1994.

Vokler Koop/Dietmar Schössler. Erbe NVA, Bundeswehr Academy for Information und Communication, 1992.

Werner v. Scheven. "Die Vereniging der ehemaligen feindlichen deutschen Armeen", AuBenpolitik. 2/92, 1992.

"Der Weg zur Einheit" - Information zur politischen Bildung, brochure No. 250.

"Nach vier Jahrzenten" - Arbeitsgemeinschaft Jugend und Bildung/Bundeszentrale für politische Bildung, Bonn, 1992.

"Deutschland ist Eins - Der Einigungsvertrag", Press and Information Office of the Federal Government, 1990.

"Ein Staat - Eine Armee", Von der NVA zur Bundeswehr, Per Joachim Lapp, Forum Deutsche Einheit, No. 9. 